\title{
CLIMATE CHANGE AND TEACHER'S PERFORMANCE IN SECONDARY SCHOOL IN BENUE STATE NIGERIA
}

\author{
Ortsa Gabriel Mhenbee ${ }^{*}$, Akwam Jane Ndidiamaka ${ }^{2}$ \\ 1,2Benue State University, Makurdi, Nigeria \\ *akwamjane@gmail.com
}

\section{Article Info}

\section{Article history}

Received May 13, 2021

Revised May 18, 2021

Accepted July 22, 2021

Keywords: Benue State. Climate Change; Secondary

School and Teachers'

Performance.

\begin{abstract}
The study investigated climate change and Teachers' performance in secondary schools in Benue State, Nigeria. Two research questions and two hypotheses guided the study. A survey research design that the population compromised 5,225 teachers from 512 secondary schools. A total of $528(10 \%)$ teachers from 51 (10\%) secondary schools sample using a proportionate stratified sampling technique: A 10-items self-structured questionnaire titled climate change and teachers performance questionnaire (CCTPQ) was using for data collection. The data were analyzed using mean and standard deviation to answer the research questions, while the chi-square $\left(x^{2}\right)$ test of goodness of fit was using to test the hypotheses at a 0.05 level of significance. The study's findings that rainfall significantly impacts teachers' performance in secondary school in Benue State, Nigeria. The study also found that excessive heat has a significant impact on teachers' performance in secondary schools. It concluded that climate change significantly impacts teachers' performances in secondary school in Benue State, Nigeria. Based on the findings, it recommends that secondary principals provide rain-cut to the teacher during the rainy season to perform effectively. The government should provide Airconditions or sling fans during excessive heat in the classrooms for efficient teachers' performance.
\end{abstract}

\section{INTRODUCTION}

Nigeria has a tropical climate with two precipitations in parts of the Southwest and Southeast rainforest and mangrove. It can lead to aridity, persistent drought and desertification in the north, and erosion and large-scale flooding in the south. Climate change is a national phenomenon; the challenges associated with climate change vary across the country. Evidence also shows that weather conditions will continue to significantly impact human life and ecosystems (Amanchukwu, 2015). All sectors of the country's socio-economic development are vulnerable to climate change. Extreme weather events have become a yearly occurrence that people have not learned to prepare (Olaniyi, 2013). 
The country has experienced climate extremes in recent years, and floods are the most common, recurring disaster (Medeley as cited in Herold, Ekstrom, Kala, Goldie, \& Evans, 2017). The durations and intensities of rainfall have increased in the last three decades producing large runoffs and flooding in many places (Enete, 2014). Rising sea level and ocean surge in southern Nigeria has submerged villages in Lagos and some places in Niger Delta (Anabarange, 2019). In the Nigeria Sahelian region, there has been a 25 percent decrease in precipitation on average in the last 30 years (Olapido, 2010). The drying up of Lake Chad from around $4000 \mathrm{sq} \mathrm{km}$ to around $3000 \mathrm{sq} \mathrm{km}$ between 1960 and 2007, respectively, is attributable to the effects of climate change in that part of the country (Elisha, 2017).

Scientists have discovered that human activities such as fossil fuels and land-use change have led to an increase in the concentration of greenhouse gases in the atmosphere. These gases trap extra heat inside the atmosphere offsetting the earth's atmosphere energy balance leading to rapid changes in the earth's system that have been observed to be occurring at an increasing rate over the past two or three centuries (Madu, 2016).

Climate change refers to any change in climate over time, whether due to natural variability or as a result of human activities. It refers to a change in climate which is attributed directly or indirectly to human activities that alter the composition of the global atmosphere and which is in addition to natural variability observe over comparable periods intergovernmental panel on climate change (IPCC) (2016). It encompasses all forms of climate inconsistencies (i.e., Any differences from long-term statistics of the meteorological elements calculated for different periods but to the same area).

Climate change presents the most severe environmental challenge facing humanity in the $21^{\text {st }}$ century, manifesting in extremes of weather events such as flooding, drought, heatwaves, changes in rainfall intensity and pattern, sea-level rise, drying up of rivers, streams among others (Development partnership in Higher Education 2010). The unprecedented catastrophe presented by climate change threatens to put the already achieved humankind development into recession, posing a massive challenge to the nation's achievement of the Millennium Development Goals (MDGs).

Climate change refers to any change in the state of the climate that can identify by changes in the average and or the variability of its properties (e.g., temperature, precipitation) that persist for an extended period, typically a decade or longer (Yahaya Nwabuqso, 2016). Climate change is caused by greenhouse gases (GHGS), which enhance the greenhouse properties of the earth's atmosphere. These gases allow solar radiation from the sun to travel through the atmosphere but prevent the reflected heat from escaping back into space. It causes the earth's temperature to rise Amadi and Udo (2015). The climate system evolves with time under the influence of its internal dynamics and external factors that affect climate. External forcing includes natural phenomena such as volcanic eruptions, changes in the earth's orbit and solar variations, as well as human-induced changes (anthropogenic factors). 
Many naturally occurring reactions like the decaying of organic material and respiration both in plants and animals induce climate change via the release of greenhouse gases, e.g., carbon dioxide $\left(\mathrm{CO}_{2}\right)$, Methane $\left(\mathrm{CH}_{4}\right)$, sulphuric oxide $\left(\mathrm{SO}_{2}\right)$, le Treat (2007).

However, the leading cause of climate change has been attributed to anthropogenic activities; for example, the increased industrialization in many nations has led to the introduction of large quantities of greenhouse gases that cause climate change. The principal greenhouse gases that enter the atmosphere because of human activities are carbon dioxide (C02), methane $\left(\mathrm{CH}_{2}\right)$, Nitrous oxide (N20), and Sulfinate gases (Abdulkadir, 2007).

According to PCC (2016), rainfall refers to liquid water in droplets that condenses from atmospheric water vapor and when precipitates. This rain is a significant component of waters on the earth changing rainfall; therefore, it refers to the degree of variability in the amounts of rainfall recorded within the areas of study, which may cause flood erosion, drought, poor visibility, and climate disasters that may impact the general wellbeing or the people and teaching performance in the area of the only study.

Executive heat is the unbearable energy that spontaneously passes between a system and its surroundings in some way other than through work to the transfer of matter. It is the unbearable state of hot temperature often accompanied by high humidity. These conditions can be dangerous and even life-threatening to humans who do not take proper care of them. Excessive heat to humans who do not take proper care of them creates a problematic situation for the maintenance of discipline in schools. Both teachers and students become disoriented and disorganized. The result might be teacher ineffective performance (Abdulahi, 2005). Collaborating the above Edo and Osuji (2016) in a study on teachers and students perception of climate change dimensions on teaching/learning in secondary schools, PortHarcourt Local Government Area, Rivers State revealed that severe weather conditions, whirlwind, excessive heat were among climate change dimensions that negatively impact on the teaching and learning.

Teachers play a critical role in the teaching and learning process. Their contribution to quality education cannot be ignored (Kimeli and Chelimo, 2017). The concept of performance may mean different things to different people depending on the perspective from which one approaches it. It refers to efficiency, financial results or return (profit), or investment (Herath \& Rashi, 2013). Performance refers to an act of accomplishing to executing a given task. Performance is a measure of how workers accomplish specific and desirable results of the organization or school (Aliyu \& Palwasha, 2010).

Teachers performance is the extent to which teachers achieve school objectives by arriving at school on time, preparing lessons that involve drawing up schemes, lesson plans, records of work done, preparing and using learners and evaluating of learners, attending staff meetings, managing learners discipline, involvement in co-curricular activities as well as counseling and guidance. The quality of an education system depends on our teachers' 
performance (Ochwo, 2013). Many teachers do not attend to their duties as educators even when they are present in school. Absenteeism and failure to cover the syllabus are signs of teachers' poor performance, which affects students' overall academic achievement in school.

Effective teaching means teachers were helping their students to understand the constant knowledge and engage in learning through the classroom instructions and interactions with their students. Teaching is a reciprocal connection between teachers and students, as students are central to teachers' performance. Students' perceptions of teaching can provide more information and a more robust definition of teacher performance worth considering for inclusion in teachers' evaluation systems (Bill and Machinda, 2010). Tan and Fincher (2016) cosset that it is possible to differentiate a competent teacher from others who are not competent; this is first possible with the teaching style. Teachers also play their roles in guiding students in their academic problems. Providing guidelines to students is also an essential aspect of teachers' performance. A teacher is a good problem solver for the students, and there is a strong relationship between the method and the effectiveness of the teacher. It is against this backdrop that the researcher investigated climate change and teachers' performance in secondary schools in Benve State, Nigeria.

Sustainable development is a goal countries worldwide have been striving to achieve by instituting plans and actions to improve teachers' effectiveness against the programs and executing them for the overall interest of people. Sustainable development can be defined as development that meets the needs of the present generation without compromising the ability of future generations to meet their own needs (world commission on environment and development, 1987). It is a systematic concept relating to the continuity of economic, social, institutional, and environmental organizations that identified education as fundamental to achieving sustainable development. Since then, progress achieved was intentional, variable, and generally unsatisfactory. It necessitated the injection of a badly needed urgency in 2005 when the United Nations (UN) adopted a Decade of Education for Sustainable Development (UNESCO, 2005).

In furtherance of this, the adoption included integrating the principle's values and practices of sustainable development into all aspects of education and learning. The Idea is that such input will create a more sustainable future in terms of environmental integrity, economic viability, and just society for present and future generations Organisation for Economic Co-operation and Development (OECD, 2007). The purpose of Sustainable Development is to provide a means of configuring civilization and human activity so that society, its members, and economies can meet their needs and express their most significant potential in the present. While preserving biodiversity and natural ecosystems and planning and acting for the ability to maintain these ideas in a very long term, it emphasizes a desirable future state for human society in which living conditions and resource-use meet human needs 
with one undermining the sustainability of the natural system and the environment so that future generations may also have their needs met.

\section{Statement of the Problem}

The ineffectiveness of teachers' performance has been a matter of general concern in our society as the school system has been adversely affected. It was chiefly attributing as a result of climate change. Teachers in Benue State seem to experience irregular rainfall and excessive heat, which hinder their performance. The environment under which teachers teach or work during rainfall and excessive heat is not conducive. Hence this could reduce their interest as well as their performance in teaching.

However, the researcher's observation and personal experience have shown that climate change and teacher performance in secondary school in worrisome and have become a daily public discussion in Benue State, Nigeria. It has bordered many stakeholders in education, notable principals, staff, students, parents, and government over their likely impact on secondary schools. Against this backdrop, the researchers investigate climate change and teacher's performance in secondary schools in Benve State, Nigeria.

\section{Aims and Objectives}

This study aimed to investigate climate change and teacher's performance in secondary school in Benue State, Nigeria. The study sought to:

1. Determine the impact of rainfall on teachers' performance in secondary school in Benue State, Nigeria.

2. Ascertain the impact of excessive heat on teacher performance in secondary school.

\section{Research Questions}

The following research questions guided the study.

1. In what ways does rainfall impacts teachers ' performance in secondary school in Benue State, Nigeria?

2. What is the impact of excessive heart on teachers' performance in secondary schools?

\section{Hypotheses}

The following research hypotheses were formulated and tested at a 0.05 level of significance.

1. Rainfall has no significant impact on teachers' performance in secondary school in Benue State, Nigeria.

2. Excessive heat has no significant impact on teachers' performance in secondary schools. 


\section{METHODOLOGY}

The study adopted a descriptive survey research design. The study population comprised 5,225 teachers from 512 secondary schools in Benve State (Benve State Ministry of Education 2017). Stratified random sampling technique, the sample of 523 teachers representing $10 \%$ from 51 secondary schools was selected. The sample is considered adequate since it is in line with Achor and Ejibos (2006) assertion that the sample of $210 \%$ is adequate for a larger population. The authors further stress that the percentage could be higher or less depending on the population. A 10-items self-structured questionnaire titled Climate Change and Teachers Performance Questionnaire (CCTPQ) was used for data collection. The questionnaire was divided into sections A and B. Section A contained items into the personal data of the respondents. At the same time, section $B$ is divided into two clusters, 1 and 2. Cluster 1 contained items $1-5$, and cluster 2 contained items 6 -10, respectively. The instrument was structured on a four-point rating scale with response mode of Very High Extent (VHE) $=4$, High Extent $(\mathrm{HE})=3$, Low Extent $(\mathrm{LE})=2$ and very low Extent $(\mathrm{VLE})=1$.

The questionnaire was validated by three experts in educational management from the Faculty of Education Benue State University, Makurdi. The questionnaire was trial-tested using 20 teachers from four secondary schools who were not part of the sample but part of the population. The reliability of the instrument was measured using Cronbach Alpha which yielded a reliability coefficient of 0.85 . It indicated high internal consistency. The data collected were analyzed using mean scores and standard deviation to answer the research questions. Any item which is less than 2.50 was rejected as having no impact. On the other hand, it was accepted if 2.50 and above chi-square test of goodness-of-fit were used to test the null hypothesis at 0.05 level of significance.

\section{RESULT}

The result presents in line with the research questions and hypotheses that guide the study.

Research Question 1: How does rainfall impact teachers' performance in secondary school in Benue State, Nigeria?

Table 1. Mean and Stand Deviation on Impact of Rainfall on Teachers Performance in Secondary School

\begin{tabular}{llllll}
\hline Item & Item Description & $\mathbf{N}$ & $\overline{\mathbf{x}}$ & STD & Decision \\
\hline 1 & $\begin{array}{l}\text { Heavy rainfall prevents teachers from } \\
\text { attending lessons as planned. }\end{array}$ & 523 & 2.65 & 1.09 & Accepted \\
2 & $\begin{array}{l}\text { Rainfall brings about noise from splashing } \\
\text { raindrops, thereby affecting teachers' } \\
\text { performance. }\end{array}$ & 523 & 3.04 & .90 & Accepted \\
3 & $\begin{array}{l}\text { Running water from rainfall causes erosion } \\
\text { that destroys lessons. } \\
\text { Rainfall typically disrupts school activities in } \\
\text { which affects teachers' performance. }\end{array}$ & 523 & 2.80 & .86 & Accepted \\
\hline
\end{tabular}




\begin{tabular}{llllll}
\hline Item & Item Description & $\mathbf{N}$ & $\overline{\mathbf{x}}$ & STD & Decision \\
\hline 5 & $\begin{array}{l}\text { Heavy rainfall impacts school resource } \\
\text { allocation, especially infrastructures. } \\
\text { Cluster mean and Standard Deviation }\end{array}$ & 523 & 3.03 & 1.01 & Accepted \\
\hline
\end{tabular}

Table 1 shows the mean scores of items $1-5$ as follows: 2.65, 3.04, 2.80, 2.78, 3.03 with a correspondent standard deviation of $1.09, .90, .86,1.15$ and 1.01 respectively. With a cluster mean of 2.86 and a standard deviation of 1.00 above the mean cut-off point of 2.50 . The result thus indicated that all the items are accepted. It implies that rainfall impacts teachers' performance in secondary school in Benve State, Nigeria.

Research Question 2: What is the impact of excessive heat on teachers' performance in secondary school?

Table 2. Mean and Standard Deviation on the Impact of Excessive Heat on Teachers' Performance in Secondary School

\begin{tabular}{llllll}
\hline Item & Item Description & $\mathbf{N}$ & $\overline{\mathbf{x}}$ & STD & Decision \\
\hline 6 & $\begin{array}{l}\text { Teachers are usually rowdy and } \\
\text { disorganized during intense heat periods. }\end{array}$ & 523 & 2.79 & .91 & Accepted \\
7 & $\begin{array}{l}\text { Heat brings about teachers pulling off their } 523 \\
\text { shrink buttoning during lessons. }\end{array}$ & 2.84 & .90 & Accepted \\
8 & $\begin{array}{l}\text { Teacher sweet heavy during a lesson when } 523 \\
\text { in heat period. }\end{array}$ & 2.50 & 1.09 & Accepted \\
9 & $\begin{array}{l}\text { Teachers put on skimpy dresses in lesson } \\
\text { halls during heat periods. }\end{array}$ & 523 & 3.05 & .84 & Accepted \\
\hline 10 & $\begin{array}{l}\text { Heat personal made teachers not to } \\
\text { attended lessons on time. } \\
\text { Cluster mean and Standard Deviation }\end{array}$ & 523 & 3.00 & 1.11 & Accepted \\
\hline
\end{tabular}

Table 2 shows the mean scores of items $6-10$ as follows: 2.79, 2.84, 2.50, 3.05 and 3.00 with a correspondent standard deviation of $.91, .90,1.09, .84$ and 1.11 respectively. With a cluster mean of 2.84 and a standard deviation of .97 above the mean cut-off point of 2.50 . The result thus indicated that all the items are accepted. It means that excessive heat has an immense impact on teachers' performance in secondary school.

\section{Testing of Hypotheses}

Hypothesis 1: Rainfall has no significant impact on teachers' performance in Benue State, Nigeria.

Table 3. Chi-Square Analyses on the Impact of Rainfall on Teachers Performance in Secondary School

\begin{tabular}{lllllll}
\hline Responses & $\mathbf{0}$ & $\mathbf{e}$ & df & $\mathbf{x}^{2}$ Cal. & $\mathbf{p}$ & Decision \\
\hline Very Low Extent & 77 & 130.8 & & & & \\
Low Extent & 75 & 130.8 & & & & \\
High Extent & 125 & 130.8 & 3 & 147.707 & .000 & Significant \\
Very High Extent & 246 & 130.8 & & & & \\
Total & $\mathbf{5 2 3}$ & & & & & \\
\hline
\end{tabular}


Table 3 shows that $x^{2}=147.707, d f=3, p=.000<0.05$. Since the $p$-value is less than the alpha level of 0.05 , the null hypothesis states that rainfall has no significant impact on teachers' performance in secondary school in Benue State, Nigeria, is rejected. It means that rainfall significantly impacts teachers' performance in secondary school in Benve State, Nigeria.

Hypothesis 2: Excessive heat has no significant impact on teachers' performance in secondary schools.

Table 4. Chi-Square Analyses on the Impact of Rainfall on Teachers' Performance in Secondary School

\begin{tabular}{lllllll}
\hline Responses & $\mathbf{0}$ & $\mathbf{e}$ & $\mathbf{d f}$ & $\mathbf{x}^{2}$ Cal. & $\mathbf{p}$ & Decision \\
\hline Very Low Extent & 100 & 130.8 & & & & \\
Low Extent & 25 & 130.8 & & & & \\
High Extent & 175 & 130.8 & 3 & 172.824 & .000 & Significant \\
Very High Extent & 223 & 130.8 & & & & \\
Total & $\mathbf{5 2 3}$ & & & & & \\
\hline
\end{tabular}

Table 4 shows that $x^{2}=172.824, d f=3, p=.000<0.05$. Since the $p$-value is less than the alpha level of 0.05 , the null hypothesis that excessive heat has no significant impact on teachers' performance in secondary schools was rejected. It implies that excessive heat has a significant impact on teachers' performance in secondary schools.

\section{Discussion of Findings}

The first finding reveals that rainfall significantly impacts teachers' performance in secondary school in Benve State, Nigeria. It means that rainfall compels teachers to miss classes/lessons, even when it distracts the rainy environment and at times disrupts school activities, which tend to affect teachers' performances in schools. This finding is in line with the Development partnership in Higher Education (2010), whose report revealed that climate change presents the most severe environmental challenge facing humanity in the $21^{\text {st }}$ century, manifesting in extremes of weather events such as flooding, drought, heatwaves, changes in rainfall intensity and pattern, sea-level rise, drying up of rivers, streams among others.

The second finding reveals that excessive heat has a significant impact on teachers' performance in secondary schools. It entails that heat creates discomfort for teachers, making them disorganized, thereby intruding into their performances. This finding is consistent with Edo and Osuji (2016), whose results also indicated that severe weather conditions, whirlwinds, excessive heat were among climate change dimensions that negatively impact teaching and learning.

\section{CONCLUSION}

Based on the findings of this study, the following conclusion is drawn; climate change in the areas of rainfall and excessive heat has a significant impact on teachers performance in 
secondary schools; this is upon the premise that rainfall compels teachers to miss classes/lessons, even when in classes it distract the raining environment and at times disrupts school activities which tend to affects teachers performances in schools and heat, on the other hand, creates discomfort for teachers making them become disorganized thereby intruding into their performances. The following recommendations are put forward in line with the study findings: 1) Teachers should be sensitized through workshops, seminars, and conferences on how to adapt to changing climatic conditions in contemporary society to cover the challenges affecting their performances. 2), principals should provide rain-cut to teachers during the rainy season to enable them to perform effectively. and 3) Proper adaptation, mitigation, and collaboration among various stakeholders' strategies should be the approach facilities that can regulate by providing well-ventilated classroom/offices fans and air conditioners to combat the effects on teaching and learning.

\section{REFERENCES}

Abdulkadir, A. (2012). Climate change and its implication on human existences in Nigeria: a review. Bayer Journal of Pure and Applied Sciences, 10(2), 152-158.

Abdullahi, F. (2015). Impact of climate change on regional development of science. Environmental Science Research Journal, 17(2), 112-119.

Achor, E, E, \& Ejigbo, M. A. (2006). A guide to writing a research report. Kano: Sam Artrade Limited.

Aliyu, E. A. \& Palwasha, A M. (2010). Motivation and performance of academic staff or state universities in Nigeria. International Journal of Business and Management 7(14), 14-29).

Amadi, S. O. \& Udo, S. O. (2015). Climate change in contemporary Nigeria: An empivied analysis of trend impacts challenges and coping strategies. Journal of Applied Physics $7(2), 1-5$.

Amanchukwu, R. N. (2015). Climate change education in Nigeria: The role of curriculum review. Education 5(3), 71-75.

Anabaraonye, B. (2019). Educating farmers and fishermen in rural areas in Nigeria on climate change mitigation and adaptation for global sustainability. International Journal of Scientific and Engineering Research, 10(4) 1391-1398.

Bill \& Malinda Gates Foundation (2010). Working with teachers to develop fair and reliable measures of effective teaching: MET Project Research Paper.

Development Partnership in Higher Education (2010). A Framework for Agricultural Adoption to climate change in Sansthan Nigeria. A Research resort project 326.

Edo, B.L. \& Osuji, C. (2016). Teachers and students perception of climate change dimensions on teaching/learning in secondary schools, Port-Harcourt Local Government Area, Rivers State. International Journal of Education and Evaluation, 2(3), 43-50 
Elisha, I. (2017). Evidence of climate change and adaptation, Strategies among grain farmers in Sokoto State. Nigeria: Journal of Environmental Sciences, Toxicology and Food Technology, 11 (3), 1-7.

Enate, IC (2014). Impact of climate change on Agricultural Production in Enugu State, Nigeria Journal of Earth Science and climate change. 5(9) 224.

Herath, H. M. A. \& Roshi, M. (2013). Strategic Orientation based research model of SMEs performance for developing countries. Review of integrative Business and Economic Research, 2(1) 430-440.

Herold N., Ekstrom, M. Kala, J., Goldie, J. and Evans, J.P. (2017). Australian climate extremes in the 21 st century according to a regional climate model ensemble: Implications for health and agriculture. Weather and Climate Extremes xxx, 1-15

Intergovernmental Panel on climate change (IPCC) (2010). Climate change impacts, adaptation and vulnerability. 13/11/2007.

Kimeli R.D. \& Chelimo, F.J. (2017). General Perspective of Teacher Evaluation. International Journal of Scientific \& Engineering Research, 8(6), $2031-2034$

Le Treat, R. (2007). Motivating people on the way towards organizational performance. Covalence analyst papers 1-4.

Madu, I. A. (2006). Rurality and climate change vulnerability in Nigeria: Assessment towards evidence-based even rural development policy. Paper presented of the 2016 Beshi conference on Global Environmental change 23-24 May 2016 at Freie University Berlin.

Ochwo, P. (2013). Pupil Teachers and school factors that influence student achievement on the primary leaving examination in Uganda: measuring development and multi-level modeling. Unpublished Doctoral Dissertation Kent State University College, Kent.

Olaniyi, O. A. (2013). Review of climate change and its effect on Nigeria ecosystem. International Journal of African and Asian Studies 1, 57.

Olapdido, E. (2010). Towards enhancing the adopting capacity of Nigeria: a review of the country's state of preparedness for climate change adapting. Heinrich Ball Foundation Nigeria.

Organisation for economic co-operation and Development (OECD) (2007). Higher education for sustainable development: Final Report of international Action Research Project.

Tan, S.K.S \& Fincher, M.D. (2016) Differences in Novice and Competent Teachers' Knowledge. Retrieved from https://www.researchgate.net/publication/249035755 on 17/07/2021

Tumilaar, B. R. (2015). The effect of discipline, leadership, and motivation on employee performance. Journal of Konomi 3(2), 42-57.

UNESCO (2005). United Nations decade of education for Sustainable development: 2005-2014. World commission on environment and development (1987). Our common future: report of the world commission on environment and development. 
Yahaya, O. \& Nwabuogo, O. E. (2016). Renewable energy deployment as climate change mitigation in Nigeria. Global Journal of Human-Social Science 16(4). 